Anais da Academia Brasileira de Ciências (2005) 77(1): 103-111

(Annals of the Brazilian Academy of Sciences)

ISSN 0001-3765

www.scielo.br/aabc

\title{
A reassessment of the role of serotonergic system in the control of feeding behavior
}

\author{
MAGDA A. MEDEIROS, RICARDO H. COSTA-E-SOUSA, EMERSON L. OLIVARES, \\ WELLINGTON S. CÔRTES and LUÍS C. REIS \\ Departamento de Ciências Fisiológicas, Instituto de Biologia \\ Universidade Federal Rural do Rio de Janeiro, BR 465, Km 07, 23890-000 Seropédica, RJ, Brasil \\ Manuscript received on February $2^{\text {nd }}$, 2004; accepted for publication on September 9, 2004; \\ presented by FrEDERICO G. GRAEFF
}

\begin{abstract}
The role of serotonergic system in the feeding behavior was appraised by electrolytic lesions in the dorsal raphe nucleus (DRN) and administration of para-chlorophenylalanine (PCPA, $3 \mathrm{mg} / 5 \mu \mathrm{l}$, icv). Chronic evaluations were accomplished through 120 and 360 days in PCPA-injected and DRN-lesioned rats, respectively. Acute food intake was evaluated in fasted rats and submitted to injection of PCPA and hydroxytryptophan (LHTP, $30 \mathrm{mg} / \mathrm{kg}$, ip). DRN-lesioned rats exhibited $22-80 \%$ increase in food intake up to sixth month, whereas the obesity was evident and sustained by whole period. In PCPA-injected rats was observed an initial increase in the food intake followed by hypophagy from $25^{\text {th }}$ to $30^{\text {th }}$ day and a transitory increase of body weight from $5^{\text {th }}$ to $60^{\text {th }}$ day. In the acute study, the LHTP reverted partially the PCPA-induced increase in food intake of fasted rats suggesting a sustained capacity of decarboxylation of precursor by serotonergic neurons. Slow restoration of the levels of food intake in DRN-lesioned rats reveals a neuroplasticity in the systems that regulate feeding behavior. A plateau on the body weight curve in lesioned rats possibly represents the establishment of a new and higher set point of energetic balance.
\end{abstract}

Key words: food ingestion, serotonergic system, dorsal raphe nucleus, electrolytic lesion, para-chlorophenylalanine, obesity.

\section{INTRODUCTION}

Evidences have implicated the serotonergic transmission in the feeding behavior. Basomedial nuclei of hypothalamus and lateral hypothalamic area, admittedly involved with feeding behavior control, are innervated by serotonin neurons from the midbrain raphe (Azmitia and Segal 1978, Parent et al. 1981). Studies with administration of serotonin precursors (Fernstrom and Wurtman 1971a, b, Fernstrom 1983), inhibitors of serotonin presynaptic uptake, serotonin releasers, inhibitor of trypto-

Correspondence to: Luís Carlos Reis

E-mail: lcreis@ufrrj.br phan hydroxylase and receptor agonists of serotonin (Blundell 1984, 1991) are concordant with the serotonergic hypothesis of appetite modulation. Postsynaptic receptors 5HT1B and 5HT2C are the more relevant for the anorexigenic response in mammals and birds (Blundell 1984, 1991, Curzon 1990, 1991, Cedraz-Mercez et al. 2004, unpublished data). This statement was corroborated by Tecott et al. (1995), Nonogaki et al. (1998), Chou-Green et al. (2003) who showed that 5HT2C knockout mice develop hyperphagia and adiposity. In addition, hyperphagia and obesity after brain serotonin depletion induced by inhibition of tryptophan hydroxylase, or 
after neurotoxic lesion of serotonin neurons, have reinforced the serotonergic hypothesis (Breisch et al. 1976, Saller and Stricker 1976).

Recent studies demonstrated the participation of other two systems of food intake control, the leptin, hormone secreted by adipocytes after increase of fat in the adipose tissue and, the orexin A, a neuropeptide which is expressed in the lateral hypothalamus after fasting and subsequent energy depletion (Janeckova 2001, Rodgers et al. 2002). Leptin reduces food ingestion and additionally stimulates mechanisms within basomedial hypothalamus concerned to fat oxidation, energetic balance and, therefore, the body weight as well (Friedman and Halaas 1998, Grill and Kaplan 2002).

Subset of serotonin neurons within the raphe nuclei co-expresses serotonin transporter mRNA and leptin receptor mRNA (Finn et al. 2001). In this line of reasoning, Fernández-Galaz et al. (2002) evidenced the leptin uptake by serotonin neurons of the dorsal raphe nucleus (DRN) and Yamada et al. (2003) showed that the hypophagic effect of leptin is mediated by serotonergic activity and subsequent 5HT2C receptor stimulation. On the other hand, orexin A receptors were identified in serotonin neurons of the DRN on which its excitation possibly constitute a negative feedback loop for acute control of food ingestion, particularly carbohydrates (Brown et al. 2001).

However, evidences concerning the role of DRN ascending pathways in the regulation of feeding behavior are inconclusive. Observations concerning lesions are controversial in spite the above mentioned reports. Thus, Geyer et al. (1976) showed that electrolytic lesions of B7 area, corresponding DRN, didn't produce significant alterations in the food ingestion and gain of body weight, as well. When lesion was directed to B8 area, corresponding median raphe nucleus (MRN) the authors reported an increase of the food ingestion and body weight (Geyer et al. 1976, Blundell 1984). It is interesting to record that, these observations were made in 6 months old rats through 4 weeks. In opposing, Heym and Gladfelter (1982) don't evi- denced increase of food ingestion in young rats in same range of age and body weight between 150 and $200 \mathrm{~g}$. In addition to those contradictory data, no evidence has been reported regarding body weight gain time course relatively to food ingestion in a longer observation period.

In the current study we reassessed the role of the serotonergic system in the control of food ingestion. New approaches were now justified considering the convergence of recent evidences for the role of serotonergic circuitry of DRN in the regulation of appetite and satiety mechanisms. Acute experiments were carried out in adult rats which received para-chlorophenylalanine (PCPA) into brain lateral ventricle and were submitted to fasting on the $4^{\text {th }}$ day after microinjection and then treated with l-hydroxytryptophan (LHTP). In chronic experiments, adult rats were treated with PCPA or submitted to DRN lesion and evaluated by 120 and 360 days, respectively.

\section{MATERIALS AND METHODS}

\section{Animals and General Procedures}

Wistar male rats from Fundação Oswaldo Cruz weighing 270-280 g were employed after previous adaptation to metabolic cage during one week. The animals were maintained under ad libitum offer of food and water. Experimental protocols were performed in laboratory with temperature control $\left(25^{\circ} \mathrm{C}\right)$ and lights on from 7:00 h to 19:00 h. Food ingestion was determined in the metabolic cages provided with chow container. Measurement of food ingestion was made by electronic precision scale in a cumulatively way, in the acute experiments and by $24-h$ interval in chronic evaluations. Experimental procedures were accomplished according to Brazilian College of Animal Experimentation and pertinent to Brazilian legislation.

IMPlantation of CANUlaE INTO LATERAL BRAin VENTRIClE AND MiCROINJECTIONS

Intracerebroventricular (icv) microinjections were made by steel cannulae implanted bilaterally into 
brain lateral ventricles in anesthetized rats $(2.5 \%$ tri-bromoethanol, ip). Cannulae were placed by employing a stereotaxic device using the following coordinates: anterior-posterior, $0.9 \mathrm{~mm}$ posterior to bregma; lateral, 1.2-1.4 mm; vertical, 3.2-3.4 $\mathrm{mm}$ from skull calvaria (Paxinos and Watson 1986). Microinjections were made with a $10-\mu 1$ Hamilton microsyringe.

\section{Brain Serotonin Depletion}

Brain serotonin depletion was produced by icv microinjection of para-chlorophenylalanine methyl ester (PCPA, Sigma, St Louis, Mo, USA) an irreversible inhibitor of the tryptophan hydroxylase (TPO) at the dose of $3 \mathrm{mg} / 5 \mu \mathrm{l}$, bilaterally, during 2 minutes under light anesthesia as described elsewhere (Breisch et al. 1976, Koe and Weissman 1966, Reis et al. 1994, Cooper et al. 1996). Control group was treated with isotonic saline $(5 \mu 1, \mathrm{icv}$, bilaterally). Acute experiments were fulfilled 4 days after icv microinjection. Chronic experiments were initiated after restoration of anesthesia effect.

\section{ELECTROLYTIC LeSIONS OF DRN}

Electrolytic lesions of DRN were produced in rats anesthetized with tribromethanol (2.5\%, ip), which were fixed in a Kopf stereotaxic device. DRN was placed through following coordinates (according to Paxinos and Watson atlas): anterior-posterior, 7.6$7.8 \mathrm{~mm}$ posterior to bregma; lateral, $0.0 \mathrm{~mm}$; vertical, 6.2-6.4 mm from skull calvaria (Paxinos and Watson 1986). Lesions were produced by passing an anodal current $(2 \mathrm{~mA}$, DC, for $10 \mathrm{sec})$ through nickel-chrome electrode guided into DRN. Control group received identical maneuver except current delivery (sham lesion). Isolated group of 12 rats were sacrificed 30 days after DRN electrolytic lesion under profound anesthesia. Transcardiac infusion was made with saline and $10 \%$ formaldehyde and the brains were arrested for histological analysis. Confirmation of lesions was made by histological examination of coronal sections through the midbrain ( $10 \mu \mathrm{m}$ thickness) stained by cresyl violet.

\section{EXPERIMENTAL Procedures}

Investigations were carried out in three experimental sets:

1) PCPA-treated rats were 24 hours fasted from the $4^{\text {th }}$ day post-microinjection $(\mathrm{N}=10)$. In following day, fasted rats were given 1-hydroxytryptophan, immediate precursor of serotonin synthesis (LHTP, Sigma, St Louis, Mo, USA) at the dose of $30 \mathrm{mg} / \mathrm{kg}$, ip. Control group received isotonic saline $(1 \mathrm{ml} / \mathrm{kg}$, ip) $(\mathrm{N}=12)$. Both groups were further returned to metabolic cages. Food ingested was determined cumulatively through 3 hours from 19:00 hours.

2) PCPA-treated rats recovered from anesthesia effect were returned to cages $(\mathrm{N}=10)$ where chronic evaluation of food ingestion and body weight were made during 120 days. Control group was injected with saline $(\mathrm{N}=12)$ and also transferred to cages.

3) DRN-lesioned $(\mathrm{N}=10)$ and sham lesion rats were returned to cages after recovery of anesthesia effect and observed through 360 days in which food ingested and body weight were determined.

\section{Statistical analysis}

Results were reported as means \pm SE. Data were analyzed statistically by two-way analysis of variance with repeated measures, and the significance between means was determined by the NewmanKeuls test. Differences between means were considered to be significant when $P<0.05$.

\section{RESULTS}

PCPA-treated and -fasted rats displayed more intense food ingestion compared to controls (Figure 1). Previous administration of LHTP reduced significantly the ingestive response but at superior level in comparison to controls $(P<0.05$, at 60,120 and 180 minutes, respectively) (Figure 1). In chronic evaluation, PCPA-treated and control rats showed a transitory phase of hypophagy resulting of surgery 
until the second day after central administration. However, from the $5^{\text {th }}$ day serotonin-depleted rats presented an intense hyperphagia with gradual decrease from $15^{\text {th }}$ day $(P<0.05)$ (Figure 2). After transitory phase of hypophagy between $25^{\text {th }}$ and $30^{\text {th }}$ day PCPA-treated rats returned to control levels of food ingestion. At $40^{\text {th }}$ day the mean values of food ingestion in PCPA-treated group were equivalent to controls. Body weight gain initiated on $5^{\text {th }}$ day and maintained high in plateau way up to $60^{\text {th }}$ day $(P<0.05)$ and became comparable to controls at $90^{\text {th }}$ day $(P>0.05)$ post-injection (Figure 3$)$.

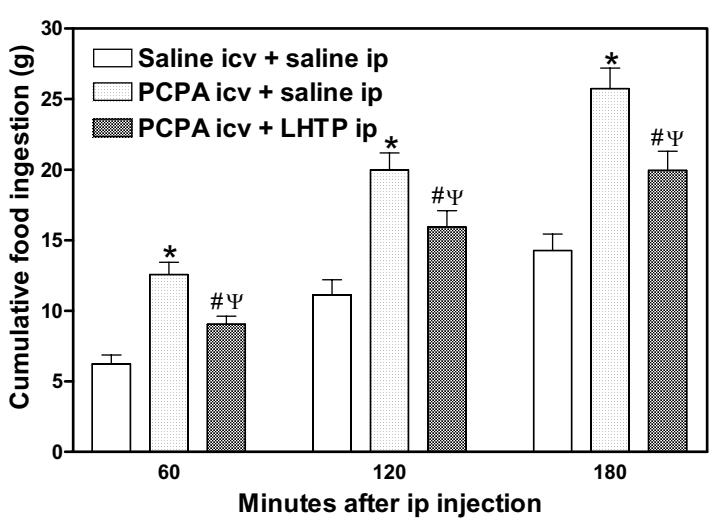

Fig. 1 - Acute effect of the previous icv PCPA microinjection $v s$ ip LHTP injection on the food intake in nocturnal fasted rats. Data are presented as mean \pm standard error at 60,120 and $180 \mathrm{~min}$. ${ }^{* \Psi} P<0.05$ compared to control group. ${ }^{\#} P<0.05$ compared to PCPA, icv + saline, ip (ANOVA and Newman-Keuls test).

Typical electrolytic lesions of the DRN extended in anterior-posterior direction (AP, 7.2-8.3 $\mathrm{mm}$ posterior to bregma) along rostral-dorsal and ventral-medial regions (Figure 4). DRN-lesioned rats displayed an intense hyperphagia from the $5^{\text {th }}$ day post-surgery $(P<0.05)$ (Figure 5$)$. This response maintained by 145 days on which the level of food ingestion remained higher than $30 \mathrm{~g}$, whereas the sham lesioned rats continued in the $20 \mathrm{~g}$ level. From the $150^{\text {th }}$ to $360^{\text {th }}$ day the levels of food ingested in DRN-lesioned group were comparable to controls. Body weight of the DRN-lesioned rats increased drastically from the $5^{\text {th }}$ day in comparison to controls $(P<0.05)$ (Figure 6). This feature main-

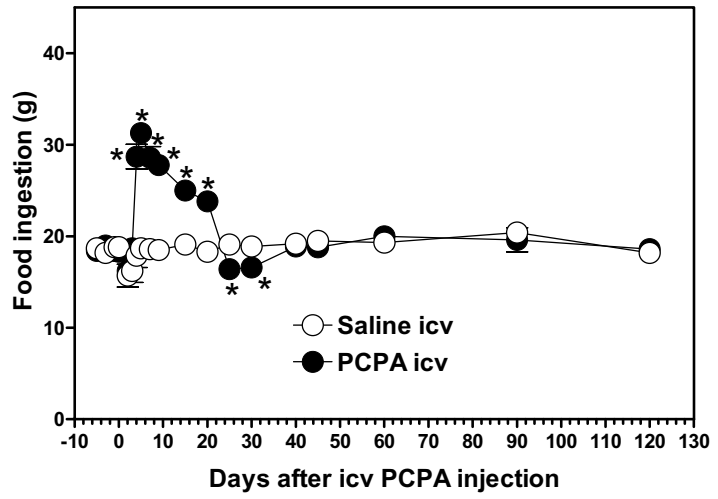

Fig. 2-Chronic effect of the icv injection of PCPA on food intake in rats. Data are presented as mean \pm standard error. $* P<0.05$ compared to sham lesion group (ANOVA and Newman-Keuls test).

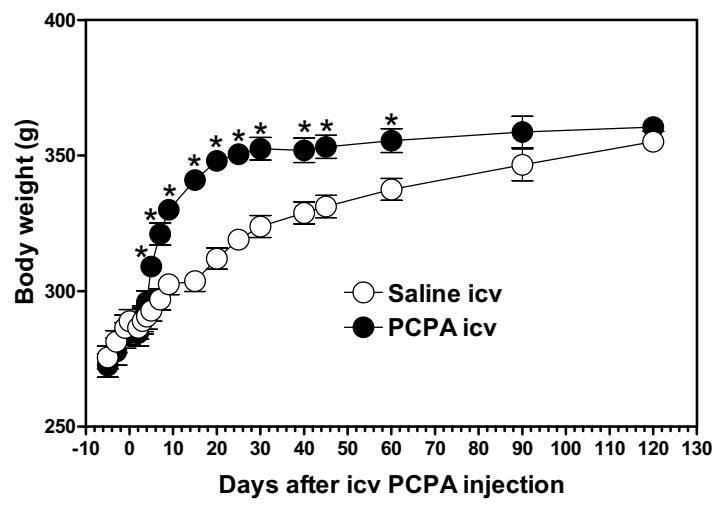

Fig. 3 - Chronic effect of the icv injection of PCPA on the body weight in rats. Data are presented as mean \pm standard error. ${ }^{*} P<0.05$ compared to sham lesion group (ANOVA and Newman-Keuls test).

tained until the moment from which it developed a plateau significantly higher than controls ones, in spite the levels of food ingested between groups have been equivalent $(P<0.05)$ (Figure 6$)$.

\section{DISCUSSION}

Results showed that PCPA-treated fasted rats expressed more intense ingestive response than the controls, presumably because the brain serotonin depletion exacerbated the orexigenic pathways activity. LHTP administration reverted partially the 
A

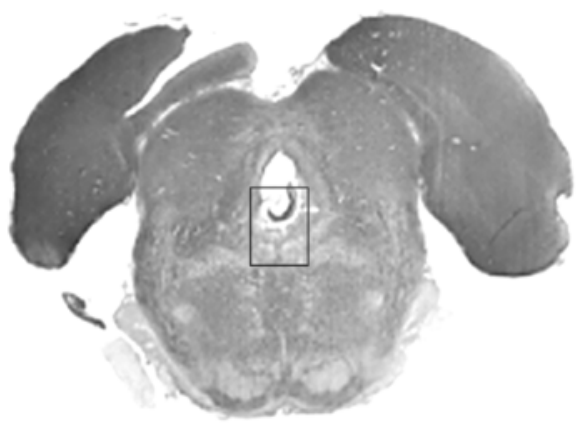

B

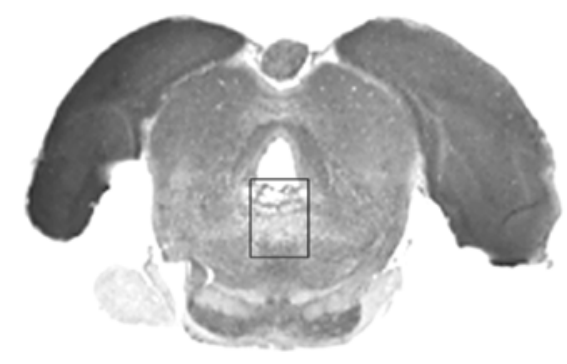

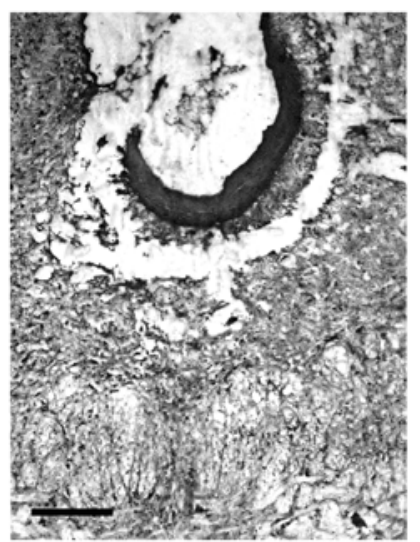

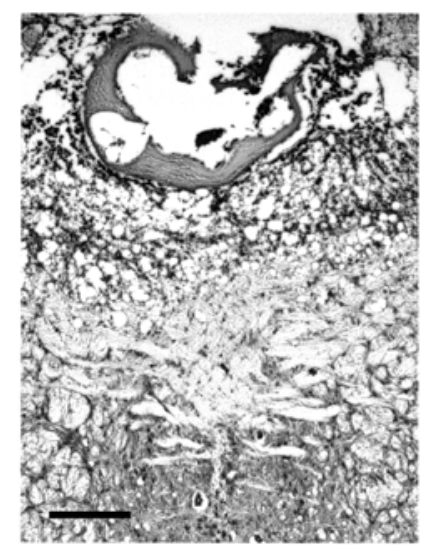

Fig. 4 - Histological sections (10 $\mu$ m thickness), stained by cresyl violet, showing typical lesion of the DRN extending from $7.2 \mathrm{~mm}$ (panel A) to $8.3 \mathrm{~mm}$ posterior (panel B) to the bregma. Note topographical references around the delimited area. Aq: aqueduct; mlf: medial longitudinal fasciculus; pi: pineal gland; bar calibration, $200 \mu \mathrm{m}$.

orexigenic response of the brain serotonin-depleted fasted rats. We presume that these conditions the serotonin neurons preserve the ability of decarboxylate the LHTP for synthesis of serotonin. These results possibly mean that serotonergic circuits are recruited during physiological ingestive process for the modulation of appetite intensity. In this context, the participation of the other systems of modulation must not be discarded. In chronic evaluation, the PCPA-treated rats expressed hyperphagic response concomitantly to a gradual increase of gain of body weight. These observations are similar to those reported by Breisch et al. (1976). However, we evidenced a gradual decrease of ingestive levels followed by hypophagy between $25^{\text {th }}$ and $30^{\text {th }}$ day af- ter icv microinjection and posterior normalization. Body weight gain was slowly reverted, achieving normalization from $90^{\text {th }}$ day post-administration of PCPA. Our results suggest that the restoration of ingestive levels and body weight demanded plasticity of the serotonin neurons induced by indoleamine depletion and inhibition of TPO. Possibly, after metabolic clearance of PCPA occurred a resettlement of TPO levels operated by de novo synthesis of that enzyme and subsequent production of serotonin. Hypophagy between $25^{\text {th }}$ and $30^{\text {th }}$ day after PCPA microinjection probably reverberate the overexpression of TPO, based on similar conclusions postulated elsewhere (Richard et al. 1990, Lima et al. 2004). Presumably, the normalization of 


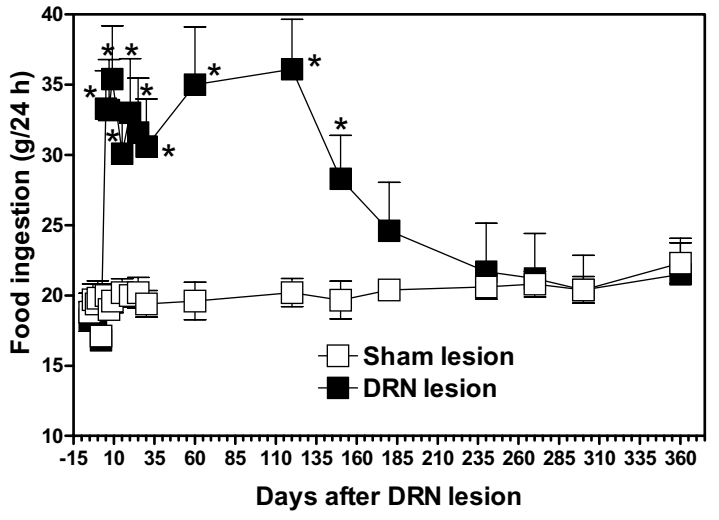

Fig. 5 - Chronic effect of the electrolytic lesion of DRN on the food intake in rats. Data are presented as mean \pm standard error. $* P<0.05$ compared to sham lesion group.

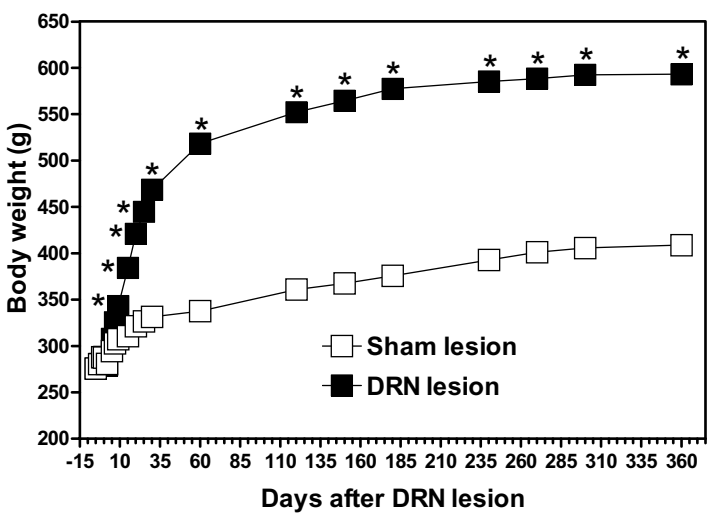

Fig. 6-Chronic effect of electrolytic lesion of DRN on the body weight in rats. Data are presented as mean \pm standard error. $* P<0.05$ compared to sham lesion group.

the serotonin turnover, and possibly high compensatory expression of other anorexigenic pathways (simultaneously to activation of control systems of the energetic balance), would restore the set point of body weight.

Data concerned to DRN-lesioned rats disclose that suppression of ascending circuits influenced the modulation mechanism of orexigenic activity as well as of energetic balance set point operation and therefore, of body weight adjustment. In this respect our observations parallel with findings regarding lesion of hypothalamic ventromedial nucleus (VMN) (Brobeck et al. 1943, Tepperman et al.
1943, Bray and York 1979, Hallonquist and Brandes 1983, Vilberg and Keesey 1984). These authors referred an intense increase of the food ingestion associated with obesity for long time. Hallonquist and Brandes (1983) showed a gradual decrease of the ingestive levels after 12 weeks post-surgery, however, with preservation of obesity. Data of the current work represent the former study of the feeding behavior in raphe-lesioned rats showing similar feature to those achieved in VMN-lesioned rats. In other papers, the data regarded to hyperphagia $v s$ obesity are controversial possibly because the authors employed young rats and, in addition they performed the evaluations for a shorter period. Long time evaluation allows us to evidence either the restoring of food intake levels, 6 months after DRN lesion and the maintenance of high adiposity index. The recovery of the mean values of food ingestion suggests the achievement of a new homeostatic status possibly consequent to orexigenic activity modulatory system plasticity. Future studies shall elucidate which neural circuit arranges that plasticity reaction. Is tempting to hypothesize that negative feedback loop from hypothalamus or originating at peripheral sites would constitute one of the neural substrate disconnected by DRN lesion. This postulation is consonant with recent evidences which orexigenic neurons from lateral hypothalamus project toward DRN where synapse with serotonergic neurons (Janeckova 2001, Rodgers et al. 2002). In this line of reasoning, leptin receptors were identified on DRN serotonergic neurons and, in addition, hypophagic effect of that hormone is partially mediated by serotonergic activity (Collin et al. 2000, Finn et al. 2001, Telles et al. 2003, Yamada et al. 2003).

Our data are similar to those reached with VMN lesion in original studies of Brobeck et al. (1943) and Tepperman et al. (1943) and, reproduced later by Bray and York (1979), Hallonquist and Brandes (1983) and Vilberg and Keesey (1984). It is known at moment that among multiple disturbances caused by VMN lesion one of them is the disconnection between peripheral signal of leptin and mRNA ex- 
pression of neuropeptide Y (NPY). NPY represents the main convergence pathway of the orexigenic behavior (Hillebrand et al. 2003, Kalra et al. 2003, Kalra and Kalra 2003). Briefly, daily rhythm of mRNA NPY demands the integrity of VMN (Dube et al. 1999). The VMN coordinately with hypotalamic arcuate (AN) and dorsomedial (DMN) nuclei constitutes a circuitry responsive to leptin feedback which regulates the caloric ingestion and adjusts the energetic content of the adipose tissue (Bernardis and Berllinger 1998). Hassanain and Levin (2002) demonstrated in this context that fasted diet-induced obese (DIO) rats showed a 53\% greater reduction in the ventromedial nucleus turnover than fasted dietresistant rats. Thus, DIO-prone rats show abnormalities in brain serotonin turnover which may predispose them to become obese when dietary fat and caloric density are increased. These observations strengthen the findings of De Fanti et al. (2000) that showed a low capacity of serotonergic transmission from DRN toward VMN in Zucker rats, genetically obese. In this line, results of current study are evidences that serotonergic pathways are implicated with the acute control of food ingestion and chronically involved with the mechanisms of energetic balance set point adjustment and, therefore, with body weight regulation. These conclusions are based on (i) in the acute restoring (partially at least) of the appetite modulation in serotonin-depleted and -fasted rats induced by LHTP and, (ii) in the maintenance of obesity for long time in DRN-lesioned rats despite of the normalization of food ingestion.

\section{ACKNOWLEDGMENTS}

We are grateful to Mr Ipojucan Pereira de Souza by animal care. This study was partially supported by Conselho Nacional de Desenvolvimento Científico e Tecnológico (CNPq).

\section{RESUMO}

O papel do sistema serotonérgico no comportamento alimentar foi avaliado através de lesões eletrolíticas do núcleo dorsal da rafe (L-NDR) e da administração de para- clorofenilalanina (PCPA, $3 \mathrm{mg} / 5 \mu \mathrm{l}$, icv). Avaliações crônicas foram realizadas durante 120 e 360 dias em ratos injetados com PCPA e L-NDR, respectivamente. Avaliações agudas foram realizadas em ratos em jejum e injetados com PCPA e 1-triptofano (LHTP, $30 \mathrm{mg} / \mathrm{kg}$, ip). Ratos lesionados apresentaram um aumento de $22-80 \%$ na ingestão de alimento até o sexto mês enquanto a obesidade foi evidenciada e mantida por todo o período. Ratos injetados com PCPA apresentaram um aumento da ingestão alimentar seguido de uma hipofagia do $25^{\circ}$ ao $30^{\circ}$ dia e um aumento transitório do peso corporal do $5^{\circ}$ ao $60^{\circ}$. Agudamente, o LHTP reverteu parcialmente o aumento da ingestão de alimento em ratos tratados com PCPA e jejuados, sugerindo a preservação da capacidade de descarboxilação do precursor pelos neurônios serotonérgicos. A lenta recuperação dos níveis de ingestão alimentar em ratos lesionados revela um mecanismo de neuroplasticidade dos sistemas de regulação do comportamento alimentar. Estabelecimento de platô na curva de peso corporal dos ratos lesionados representaria o estabelecimento de um novo e mais elevado ponto de calibração do balanço energético.

Palavras-chave: ingestão de alimento, sistema serotonérgico, núcleo dorsal da rafe, lesão eletrolítica, para-clorofenilalanina, obesidade.

\section{REFERENCES}

Azmitia EC and Segal M. 1978. An autoradiographic analysis of the differential ascending projections of the dorsal and median raphe nuclei in the rat. J Comp Neurol 179: 641-668.

Bernardis LL AND Berllinger LL. 1998. The dorsomedial hypothalamic revisited: 1998 update. Proc Soc Exp Biol Med 218: 284-306.

BLundeLl JE. 1984. Serotonin and appetite. Neuropharmacology. 23: 1537-1551.

BLundell JE. 1991. Pharmacological approaches to appetite suppression. TIPS 12: 147-157.

Bray GA AND York DA. 1979. Hypothalamic and genetic obesity in experimental animals: An autonomic and endocrine hypothesis. Physiol Rev 59: 719-809.

Breisch ST, Zemlamn FP and Hoebel BG. 1976. Hyperphagia and obesity following serotonin depletion by intraventricular p-chorophenylalanine. Science 192: 382-385. 
Brobeck JR, Tepperman J and Long CNH. 1943. Experimental hypothalamic hyperphagia in the albino rat. Yale J Biol Med 15: 831-853.

Brown RE, Sergeeva O, Eriksson KS and Haas HL. 2001. Orexin A excites neurons in dorsal raphe nucleus of the rat. Neuropharmacology 40: 457-459.

Chou-Green JM, Holscher TD, Dallman MF and AKana SF. 2003. Repeated stress in young and old 5HT2C knockout mice. Physiol and Behav 70: 217226.

Collin M, Hakansson-Ovesjo ML, Misane I, Ogren SO And Meister B. 2000. Decreased 5-HT transporte mRNA in neurons of the dorsal raphe nucleus and behavioral depression in the obese leptindeficient $o b / o b$ mice. Mol Brain Res 81: 51-61.

Cooper JR, Bloom FE and Roth RH. 1996. Serotonin (5-Hydroxytryptamine) and Histamine. In: BLoom FE et al. (Eds.), The Biochemical basis of neuropharmacology, 7th ed., New York: Oxford University Press, p. 352-409.

Curzon G. 1990. Serotonin and appetite. In: Neuropharmacology of serotonin. Ann N Y Acad Sci 600: 521-531.

Curzon G. 1991. Effects of tryptophan and of 5-hydroxytryptamine receptor subtype agonists on feeding. Adv Exp Med Biol 294: 377-388.

De Fanti BA, Gavel DA, Hamilton JS and HoRwitz BA. 2000. Extracellular hypothalamic serotonin levels after dorsal nuclei stimulation of lean $(F a / F a)$ and obese (fa/fa) Zucker rats. Brain Res 869: 6-14.

Dube MG, Xu B, Kalra PS, Sninsky CA and Kalra SP. 1999. Disruption in neuropeptide $Y$ and leptin signaling in obese ventromedial hypothalamic lesioned-rats. Brain Res 816: 38-46.

Fernández-Galaz MC, Diano S, Horvath TL and Garcia-Segura LM. 2002. Leptin uptake by serotonergic neurones of the dorsal raphe. J Neuroendocrinol 14: 429-434.

FERnSTROM JD. 1983. Role of precursor availability in control of monoamine biosynthesis in brain. Physiol Rev 63: 484-546.

Fernstrom JD and Wurtman RJ. 1971a. Brain serotonin, content: Increase following ingestion of carbohydrate diet. Science 174: 1023-1025.

Fernstrom JD and Wurtman RJ. 1971b. Brain sero- tonin content: Physiological dependence on plasma tryptophan levels. Science 73: 149-152.

Finn PD, CunNingham MJ, Rickard DG, Clifton DK AND STEINER RA. 2001. Serotonergic neurons are targets for leptin in the monkey. J Clin Endocrinol Metab 86: 422-426.

Friedman JM and HalaAs JL. 1998. Leptin and regulation of body weight in mammals. Nature 395: 763-770.

Geyer MA, Puerto A, Menkes DB and Segal DS. 1976. Behavioral studies following lesions of the mesolimbic and mesostriatal serotonergic pathways. Brain Res 106: 257-270.

Grill HJ AND KaPlan JM. 2002. The neuroanatomical axis for control of energy balance. Front Neuroendocrinol 23: 2-40.

HALlONQUist JD AND BRANDES JS. 1983. Ventromedial hypothalamic lesions in rats: Gradual elevation of body weight set-point. Physiol Behav 33: 831-836.

Hassanain M and Levin BE. 2002. Dysregulation of hypothalamic serotonin turnover in diet-induced obese rats. Brain Res 929: 175-180.

Heym J AND GladFelter WE. 1982. Locomotor activity and ingestive behavior after damage to ascending serotonergic systems. Physiol Behav 29: 459-467.

Hillebrand JJG, De Wied D and Adan RAH. 2003. Neuropetides, food intake and body weight regulation: a hypothalamic focus. Peptides 23: 22832306.

JANeckova R. 2001. The role of leptin in human physiology and pathophysiology. Physiol Res 50: 443-459.

KALRA SP AND KalRa PS. 2003. Neuropetide Y: a physiological orexigen modulated by the feedback action of ghrelin and leptin. Endocrine 22: 49-56.

Kalra SP, Bagnasco M, Otukonyong EE, Dube MG AND KALRA PS. 2003. Rhythmic, reciprocal ghrelin and leptin signaling: new insight in the development of obesity. Regul Pept 111: 1-11.

Koe KB and Weissman A. 1966. p-Chlorophenylalanine: a specific depletor of brain serotonin. J Pharmacol Exp Ther 154: 499-516.

Lima HRC, Cavalcante-Lima HR, Cedraz-Mercez Pl, Costa-e-Sousa RH, Olivares El, BadauêPassos Jr D, Medeiros MA, Côrtes WS ANd Reis LC. 2004. Brain serotonin depletion enhances the 
sodium appetite induced by sodium depletion or betaadrenergic stimulation. An Acad Bras Cienc 76: 8592.

Nonogaki K, Strack AM, Dallman MF and Tecott LH. 1998. Leptin-independent hyperphagia and type 2 diabetes in mice with a mutated serotonin 5-HT2C receptor gene. Nat Med 4: 1152-1156.

Parent A, Descarries L and Beaudet A. 1981. Organization of ascending serotonin systems in the adult rat brain. A radioautographic study after intraventricular administration of $\left[{ }^{3} \mathrm{H}\right] 5$-hydroxytryptamine. Neuroscience 6: 115-138.

Paxinos G and Watson C. 1986. The Rat Brain in Stereotaxic Coordinates. $2^{\text {nd }}$ edn. Academic Press, New York, NY, USA.

Reis LC, Ramalho MJ, Favaretto AL, Gutkowska J, McCann SM and Antunes-Rodrigues J. 1994. Participation of the ascending serotonergic system in the stimulation of atrial natriuretic peptide release. Proc Natl Acad Sci USA 91: 12022-12026.

Richard F, Sanne JL, Bourde O, Weissman D, Ehret M, Casch C, Maitre M and Pujol JF. 1990. Variation of tryptophan-5-hydroxylase concentration in the rat raphe dorsalis nucleus after p-chlorophenylalanine administration. I. A model to study the turnover of the enzymatic protein. Brain Res 536: $41-45$.
Rodgers RJ, Ishit Y, HALFord JCG ANd Blundell JE. 2002. Orexins and appetite regulation. Neuropeptides 36: 303-325.

Saller CF ANd Stricker EM. 1976. Hyperphagia and increased growth in rats after intraventricular injection of 5,7-dihydroxytryptamine. Science 192: 385387.

Tecott LH, Sun LM, Akana SF, Strack AM, Lowestein DH, Dallman MF and Julius D. 1995. Eating disorder and epilepsy in mice lacking 5-HT2C serotonin receptors. Nature 374: 542-546.

Telles MM, Guimarães RB and Ribeiro EB. 2003. Effect of leptin on the acute feeding-induced hypothalamic serotonergic stimulation in normal rats. Regul Pep 115: 11-18.

Tepperman J, Brobeck JR and Long CNH. 1943. The effect of hypothalamic hyperphagia and of alterations in feeding habits on the metabolism of the albino rat. Yale J Biol Med 15: 855-874.

Vilberg TR and Keesey RE. 1984. Reduced energy expenditure after ventromedial lesions in female rats. Am J Physiol 247: R183-R188.

Yamada J, Sugimoto Y, Hirose H and Kajiwara Y. 2003. Role of serotonergic mechanisms in leptininduced suppression of milk intake in mice. Neurosci Lett 348: 195-197. 